brazilianpoliticalsciencereview

BOOK REVIEW

\title{
Defense Cooperation: The South American Experience*
}

\section{by Janina Onuki}

Universidade de São Paulo, São Paulo, São Paulo, Brazil

(Rezende, Lucas Pereira. Sobe e Desce: Explicando a Cooperação em Defesa na América do Sul. Brasília: Universidade de Brasília, 2015)

One of the main challenges for theories of international relations and trade policy is the 'security dilemma'. International security and national defense are central issues in the area of international relations; they have always been variables related to the anarchic nature of the international system, associated with the prevalence of distrust in the relationship among states. For this reason, the classic academic debate between the neorealists' and the neo-institutionalists' contrasting views has basically revolved around the quest to overcome instability, while looking for alternatives that could create space for cooperation, precisely to avoid any return to Hobbesian anarchy.

The dilemma concerns how to create state-to-state cooperation in the security and defense field. Unlike a contract in other areas such as trade, the environment, or human rights - where the premise of cooperation justifies the creation of international regimes - the area of defense and security has an element that precedes the discussion of the regime: overcoming distrust (Jervis, 1978). Given a history marked predominantly by the balance of power between great powers known for competition, relative gains and individual protection of countries - the 
tendency has been to turn to arms for protection, and for this reason cooperation has always been treated with caution.

The changes in the structure of the international system brought about by the end of the Cold War, in parallel with an alteration in the perception of threats, require another kind of defense policy and introduce new challenges for researchers in the 21st century. These challenges lie in defense diplomacy, and in the possibility of creating security communities that are formed around a common threat or community-based regional leadership. This is the case of South America, the object of study of Rezende's book.

Seen from the perspective of a middle/rising power that has had a moderately revisionist foreign policy in recent years, the asymmetries of the international order inevitably affect Brazil's regional cooperation in defense.

Lucas Pereira Rezende begins his book by asking two questions that are pivotal within the international relations' academic debate: 1) why, after all, do states cooperate? And, more specifically, 2) why do states cooperate in defense matters? These questions represent a major theoretical challenge in the international context, concerning great powers and medium-size countries. In order to answer them, the author offers an overview of IR theories and proposes a theoretical model based on a combination of different theories, which might help to explain the countries' option for increasing defense cooperation.

The process of regional integration in South America had been put on hold until quite recently. Firstly, because of the lack of progress in intergovernmental negotiations; secondly, due to uncertainties about the priority accorded to said process; and thirdly, because of the emphasis given to the commercial sphere in the last few years. However, the dialogue amongst countries of the region has made considerable advances since then. This has meant an expansion of the community to other South American countries, which in turn led to the creation of the Union of South American Countries (Unasur) in 2008, thus institutionalizing an environment that - probably due to the presence of Andean countries - makes the heightened concern with regional security more evident.

Rezende's book, based on his extensive and very thorough doctoral research, explains how defense cooperation in South America went through many ups and downs and has only been consolidated in the last few years. It is an 
innovative endeavor, both from the theoretical point of view, as it makes use of different methodologies - such as offensive realism, liberal institutionalism and constructivism - and from the empirical point of view, as it brings a set of relevant information obtained from documentary research and quantitative information on countries' investment in the area of defense, in addition to interview data on the process of foreign policy decision-making.

The first part of the book presents some useful concepts in order to explain the changes of the last decades and the standard of cooperation that was established at the end of the Cold War. Supported by the main international references in this debate, the author discusses the concept of 'new defense diplomacy', which complements the idea of military assistance by introducing investments in bilateral and multilateral agreements for the coordination of a set of joint activities, such as foreign civilian and military training, or in the area of defense administration, in the exchange of experiences for democratic control, and so on.

This is an innovative concept and marks the introduction of a series of cooperative measures, outlining a first step towards widening the dialogue. The first feature of the new defense diplomacy lies in the idea of strategic engagement. The thesis argues that engagement refers to a new behavior on the part of states which emphasizes instruments geared towards prevention, starting from relationships in order to develop mutual trust. Confidence would then be built from the collection of a set of fundamental variables: information sharing, commitment to transparency, and the creation of spaces for strengthening mutual interests in order to create a culture of cooperation.

According to Cottey and Forster (2004), defense diplomacy gains space as international changes move towards civilian-military alignment within a context of consolidation of democratic institutions. The 'democratic peace' thesis, according to which democracies do not enter into conflict with each other, would also provide support for the stability of international security. In the empirical tests conducted by the author, the regional space is quite relevant and shows the ups and downs of defense cooperation initiatives. Rezende calls attention to the usefulness of this new conceptual framework in understanding post-Cold War military cooperation agreements, as well as its limitations. 
In order to better understand the countries' engagement in defense cooperation, in the second chapter the author carries out a comprehensive review of theories of international relations; he discusses the models proposed by the traditional approaches that prevailed until the end of the Cold War - realists and neorealists -, as well as contemporary offensive realism in defense of unipolar arrangements, and the possibilities of cooperation in a context where one leadership prevails.

The intent of the review is to analyze how, in an environment with several structural constraints, cooperation is possible. Also, how classic realist theories can establish a dialogue with some newer theories such as constructivism and regional security complex theory. All this demonstrates to what extent the international conjuncture has become much more complex, both in terms of variables that challenge traditional analyses, and in the need for new concepts in order to make sense of this reality.

The second part of the book shows the results of extensive empirical research; it highlights the role of the United States in global polarity and that of Brazil in defining polarities in South America. The author presents the context in which these polarities are materializing, the challenges that have arisen over the past few decades, and builds his analysis on a broad set of data which provides a very detailed understanding of South American countries' investment in defense; Rezende also discusses the perceptions that may eventually lead to a regional cooperation complex in the field of defense, based on the policies implemented by the seven largest countries of the subcontinent.

Chapter five provides a unique analysis of defense cooperation in South America. Drawing on previous chapters, and making theoretical approaches converge with empirical data, Rezende shows how it was possible to move forward in the construction of a cooperation agenda in the area of defense and security even in a context where the schedule of the integration process was progressing slowly in other areas, mainly because of the crisis that the process itself was going through and the changes in governments.

However, the advances of integration after the creation of Unasur have helped cooperation in defense to advance as well, since President Luís Inácio Lula da Silva's government made it a priority in the Brazilian foreign policy agenda. 
Rezende highlights the context in which the South American Defense Council (CDS) was created: there were changes in the international system, the perception of new threats and of unipolarity itself. Nevertheless, a new cooperative dynamic has emerged in the region.

Cooperation in defense and the creation of the CDS have become possible at a time when Brazil concentrates more resources on defense in comparison with its neighbors. Such cooperation would be expected to increase when one reduces distrust regarding Brazil, and to fall when the country is seen as a regional imperialist threat. From this contextual perspective, comprising the period 2008 to 2013 , the author raises the hypothesis that such oscillation is not always justifiable for two reasons: 1) in unipolarity, defense cooperation is stable; and 2) the multilateral character of Brazilian foreign policy makes a supposed Brazilian unipolarity maintain the characteristics of multilateralism (REZENDE, 2015, p. 273).

What this book brings - and it has already become an important reference in the field of international relations in Brazil - is the opportunity to reflect on the advances and setbacks of Brazilian foreign policy in the field of defense cooperation. It helps us draw the limitations and challenges still present in the process of regional integration in South America, which also undergoes 'ups and downs'. Domestic politics still play an important role in this work. By taking the re-equipment of the Armed Forces as a central variable, the author defends the hypothesis that it would be the main reason why we should rethink regional cooperation and that it is strongly influenced by the International System's context.

One interesting aspect is the way in which the author traces how the postCold War has consolidated a perception about Brazil's leadership that makes a new model of cooperation among states possible, starting with defense diplomacy. The convergence around the Brazilian leadership arises from a reduction of distrust. Other empirical studies, which take the perception of public opinion as a relevant actor in foreign policy, have also revealed that there is a process of trust-building based on the projection and regional leadership of Brazilian foreign policy, centered on presidential diplomacy throughout the 2000s.

The book, which has a foreword by Celso Amorim, Brazil's former Minister for Foreign Affairs (2003-2010) and Defense (2011-2015) makes an important contribution to the area of international relations by showing how cooperation in 
defense has evolved, and provides subsidies for regional integration in an area traditionally marked by power struggles and realist competition.

Lucas Rezende's work becomes a reference on the subject thanks to its unique theoretical debate, to its empirical research (gathering a set of interviews with actors central to the decision-making process in foreign policy in the area of defense), and to the wealth of empirical data that it brings to the reader. The South American case study contributes to a reflection on alternatives not only to consolidate integration, something dear to the countries of the region, but also in the search for alternatives to overcome the security dilemma.

Revised by Priscilla Kreitlon

\section{References}

COTTEY, Andrew and FORSTER, Anthony (2004), Reshaping defence diplomacy: new roles for military cooperation and assistance. Oxford: Oxford University Press for The International Institute for Strategic Studies. 84 pp.

JERVIS, Robert (1978), Cooperation under the security dilemma. World Politics. Vol. 30 , № 02 , pp. 167-214. 